\title{
PEMBUKTIAN UNSUR KECAKAPAN DAN KEWENANGAN PARA PIHAK DALAM TRANSAKSI BISNIS E-COMMERCE
}

\author{
OLEH : \\ Hj. Yonani, SH., MH \\ (Dosen Tetap Fakultas Hukum Universitas Muhammadiyah Palembang)
}

\begin{abstract}
ABSTRAK
Keberadaan transaksi bisnis melalui internet ini membawa implikasi baru yang berbeda, dimana kegiatan bisnis yang pada awalnya dilakukan secara bertemu langsung dan bertatap muka antar para pihak, namun dengan adanya dengan adanya internet maka kegiatan bisnis dapat dilakukan secara elektronik, atau yang lebih dikenal dengan istilah electronic-commerce dan disingkat e-commerce.Pengakuan kontrak elektronik sebagai suatu bentuk perjanjian dalam Kitab Undang-Undang Hukum Perdata (KUH Perdata) Indonesia masih merupakan permasalahan yang pelik. Pasal 1313 KUH Perdata mengenai definisi perjanjian memang tidak menentukan bahwa suatu perjanjian harus dibuat secara tertulis.

Keabsahan kontrak elektronik sebagai suatu bentuk perjanjian dalam Kitab Undang-Undang Hukum Perdata (KUHPerdata) Indonesia masih merupakan permasalahan yang pelik. Pasal 1313 KUHPerdata mengenai definisi perjanjian adalah suatu perbuatan dengan mana satu orang atau lebih mengikatkan dirinya terhadap satu orang lain atau lebih. Jika mengacu pada definisi ini maka suatu kontrak elektronik dapat dianggap sebagai suatu bentuk perjanjian yang memenuhi ketentuan Pasal 1313 KUHPerdata tersebut
\end{abstract}

\begin{abstract}
The existence of business transactions through the internet brings different new implications, where business activities are initially carried out in person and face-to-face between parties, but with the existence of the internet business activities can be carried out electronically, or better known as electronic -commerce and abbreviated as ecommerce. Recognition of electronic contracts as a form of agreement in the Indonesian Civil Code (KUH Perdata) is still a complicated problem. Article 1313 of the Civil Code concerning the definition of the agreement does not determine that an agreement must be made in writing.

The validity of electronic contracts as a form of agreement in the Indonesian Civil Code is still a complicated problem. Article 1313 of the Civil Code concerning the definition of an agreement is an act in which one or more people attach themselves to one or more other people. If referring to this definition, an electronic contract can be considered as a form of agreement that complies with the provisions of Article 1313 of the Civil Code
\end{abstract}




\section{A. Latar Belakang}

Dinamika sosial masyarakat di dunia saat ini telah mengalami perubahan pesat, hal ini ditandai oleh perkembangan yang spektakuler di bidang teknologi. Salah satu perkembangan teknologi tersebut diantaranya adalah dengan ditemukannya internet yaitu teknologi yang memungkinkan kita melakukan pertukaran informasi dengan siapapun dan dimanapun orang tersebut berada tanpa dibatasi oleh ruang dan waktu. Setelah internet terbuka bagi masyarakat luas, internet mulai digunakan juga untuk kepentingan perdagangan atau bisnis. Setidaknya ada dua hal yang mendorong kegiatan bisnis dalam kaitannya dengan kemajuan teknologi yaitu meningkatnya permintaan atas produk-produk teknologi itu sendiri dan kemudahan untuk melakukan transaksi bisnis. ${ }^{14}$

Kemunculan transaksi bisnis melalui internet ini membawa implikasi baru yang berbeda, dimana kegiatan bisnis yang pada awalnya dilakukan secara bertemu langsung dan bertatap muka antar para pihak, namun dengan adanya dengan adanya internet maka kegiatan bisnis dapat dilakukan secara elektronik, atau yang lebih dikenal dengan istilah electronic-commerce dan disingkat e-commerce. Saat ini ruang lingkup internet telah mencakup hampir seluruh dunia. Pada tahun 1998 diperkirakan terdapat lebih dari seratus juta orang yang menggunakan internet dan pada tahun 1999 jumlah tersebut telah mencapai dua kali lipat. Data Monitor memperkirakan pada tahun 2005 lebih dari 300 juta orang. ${ }^{15}$

Pengakuan kontrak elektronik sebagai suatu bentuk perjanjian dalam Kitab Undang-Undang Hukum Perdata (KUH Perdata) Indonesia masih merupakan permasalahan yang pelik. Pasal 1313 KUH Perdata mengenai definisi perjanjian memang tidak menentukan bahwa suatu perjanjian harus dibuat secara tertulis.

Pasal 1313 KUH Perdata hanya menyebutkan bahwa perjanjian adalah "suatu perbuatan dengan mana satu orang atau lebih mengikatkan dirinya terhadap satu orang lain atau lebih". Jika mengacu pada definisi ini maka suatu kontrak elektronik dapat dianggap sebagai suatu bentuk perjanjian yang memenuhi ketentuan Pasal

\footnotetext{
${ }^{14}$ Agus Raharjo, Cybercrime: Pemahaman dan Upaya Pencegahan Kejahatan Berteknologi, PT. Citra Aditya Bakti, Bandung, 2002, hlm.1

${ }^{15}$ Asril Sitompul, Hukum Internet (Pengenal Mengenai Masalah Hukum di Cyberspace),Cetakan II, , PT.Citra Aditya Bakti, Bandung, 2004,hlm vi
} 
1313 KUH Perdata tersebut. Namun pada prakteknya suatu perjanjian biasanya ditafsirkan sebagai perjanjian yang dituangkan dalam bentuk tertulis (paper-based) dan bila perlu dituangkan dalam bentuk akta notaris. Selanjutnya, mengacu pada Pasal 1320 KUH Perdata, suatu perjanjian barulah sah jika memenuhi syarat subyektif (ada kesepakatan antar para pihak dan para pihak cakap untuk membuat perjanjian) dan syarat obyekif (obyek perjanjian harus jelas dan perjanjian dilakukan karena alasan yang halal).

Dalam transaksi konvensional di mana para pihak saling bertemu, tidak sulit untuk melihat apakah perjanjian yang dibuat memenuhi syarat-syarat tersebut. Permasalahan timbul dalam hal transaksi dilakukan tanpa adanya pertemuan antar para pihak. Di samping itu, transaksi komersial elektronik sangat bergantung pada kepercayaan di antara para pihak. Ini terjadi karena dalam transaksi komersial elektronik para pihak tidak melakukan interaksi secara fisik. Karena itu masalah pembuktian jika terjadi sengketa menjadi hal yang sangat penting.

Mengenai tipe pembuktian dalam kaitannya dengan transaksi komersial elektronik, Benjamin Wright, seperti yang dikutip oleh M. Arsyad Sanusi, menyatakan ada tiga tipe umum record (catatan) yang dapat diajukan di pengadilan sebagai bukti transaksi komersial elektronik, yaitu:

1. A record of the content of an electronic message at some stage in its life (catatan mengenai isi pesan elektronik),

2. A computer audit record, such as a journal noting the time at which the computer issued a message (catatan audit komputer, misalnya catatan harian mengenai waktu pesan dikeluarkan oleh komputer),

3. A statistical or analytical report generated from a computer survey of a quantity of stored data (catatan statistik atau analitis yang dihasilkan melalui survei komputer). ${ }^{16}$

\section{B. Permasalahan}

Bagaimana pembuktian unsur kecakapan dan kewenangan para pihak dalam kontrak elektronik?

\footnotetext{
${ }^{16}$ M. Arsyad Sanusi, E-Commerce: Hukum dan Solusinya, P.T. Mizan Grafika Sarana, Bandung, 2001, hlm. 99.
} 


\section{Pembahasan}

Keberadaan kontrak elektronik (e-contract) jelas merupakan perkembangan baru dalam jenis kontrak yang modern sehingga membutuhkan pengaturan yang tepat dan berdasar hukum jelas. Karena sistem transaksi perdagangan yang semual berbasis kertas bergeser ke sistem transaksi yang berbasis mon kertas(digital). Kehadiran teknologi informasi sekarang ini sedikitnya membawa dua implikasi. Implikasi tersebut berdampak di sektor ekonomi dan sektor hukum. Di sektor ekonomi, kehadiran internet cenderung membawa iklim yang makin transparan, efektif dan efisien. Di lain pihak, kehadiran internet pada sektor hukum memunculkan berbahgai persoalan yang mendasar. Salah satu persoalan hukum tersebut adalah berkaitan dengan hukum kontrak. Sampai saat ini diakui bahwa aturan hukum kontrak konvensional belum mampu menjangkau sepenuhnya secara elektronik.

Suatu informasi/dokumen elektronik dinyatakan sah apabila menggunakan sistem elektronik yang sesuai dengan ketentuan yang diatur dalam Undang-Undang ITE yaitu sistem elektronik yang andal dan aman, serta memenuhi persyaratan minimum sebagai berikut :

1. Dapat menampilkan kembali informasi/dokumen elektronik secara utuh sesuai dengan masa retensi yang ditetapkan dengan peraturan perundang-undangan,

2. Dapat melindungi ketersediaan, keutuhan, keotentikan, kerahasiaan, dan keteraksesan informasi/dokumen elektronik dalam penyelenggaraan sistem elektronik,

3. Dapat beroperasi sesuai dengan prosedur atau petunjuk dalam penyelenggaraan sistem elektronik tersebut,

4. Dilengkapi dengan prosedur atau petunjuk yang diumumkan dengan informasi, atau simbol yang dapat dipahami oleh pihak yang bersangkutan dengan penyelenggaraan sistem elektronik tersebut,

5. Memiliki mekanisme yang berkelanjutan untuk menjaga kebaruan, kejelasan, dan kebertanggung jawaban prosedur atau petunjuk. ${ }^{5}$

${ }^{5}$ Ari Juliano Gema, Apakah Dokumen Elektronik Dapat Menjadi Alat Bukti yang Sah,, Jurnal PERADI, 7 April 2008, hlm 4. 
Keabsahan kontrak elektronik sebagai suatu bentuk perjanjian dalam Kitab Undang-Undang Hukum Perdata (KUHPerdata) Indonesia masih merupakan permasalahan yang pelik. Pasal 1313 KUHPerdata mengenai definisi perjanjian adalah suatu perbuatan dengan mana satu orang atau lebih mengikatkan dirinya terhadap satu orang lain atau lebih. Jika mengacu pada definisi ini maka suatu kontrak elektronik dapat dianggap sebagai suatu bentuk perjanjian yang memenuhi ketentuan Pasal 1313 KUHPerdata tersebut.

Di dalam KUHPerdata telah diatur mengenai perjanjian dan bagaimana syarat-syarat sahnya sebuah perjanjian yaitu dalam Buku III KUHPerdata. Syaratsyarat sahnya sebuah perjanjian diatur dalam Pasal 1320 KUHPerdata. Di dalam Pasal 1320 KUHPerdata disebut empat syarat agar sebuah perjanjian itu dapat dikatakan sah, yaitu;

1. Sepakat mereka yang mengikatkan dirinya;

Sepakat adalah para pihak yang mengadakan perjanjian harus sepakat, setuju dan seia sekata dalam hal pokok daripada perjanjian yang akan diadakan tersebut. Kata sepakat tersebut dapat batal apabila terdapat unsur-unsur penipuan, paksaan dan kekhilafan. Dalam pasal 1321 KUHPerdata dinyatakan bahwa" tiada sepakat yang sah apabila sepakat itu diberikan secara kekhilafan atau diperolehnya dengan paksaan/penipuan". 6

2. Kecakapan mereka untuk membuat suatu perikatan;

Para pihak harus memiliki kecakapan menurut hukum diantara sudah dewasa dan alam keadaan sehat.

3. Suatu hal tertentu;

Suatu perjanjian harus mengenai hal tertentu artinya apa yang diperjanjikan hakhak dan kewajiban kedua belah pihak jika timbul suatu perselisihan. barang yang dimaksud dalam perjanjian paling sedikit harus ditentukan jenisnya. Bahwa barang itu sudah ada atau sudah berada di tangannya si berutang pada waktu perjanjian dibuat tidak diharuskah oleh undang-undang. Juga jumlahnya tidak perlu disebutkan, asal saja kemudian dapat dihitung atau ditetapkan.

4. Suatu sebab yang halal.

Perjanjian ini harus didasari dengan hal-hal yang tidak bertentangan dengan undang-undang yang berlaku.

\footnotetext{
${ }^{6}$ Lihat Pasal 1321 Kitab Undang-Undang Hukum Perdata
} 
Unsur pertama dan kedua disebut syarat subjektif, karena menyangkut orang atau subjek yang membuat perjanjian. Sedangkan unsur ketiga dan keempat disebut syarat objektif, karena menyangkut objek atau hal yang diperjanjikan.

Apabila salah satu dari syarat tersebut tidak terpenuhi, maka perjanjian tersebut dapat dibatalkan karena tidak sah. Masyarakat pada umumnya harus menyadari bahwa sebuah perjanjian harus dibuat secara sadar, tanpa paksaan atau khilaf. Dalam hal ini paksaan yang dimaksud ialah tekanan bathin yang membuat salah satu pihak tidak bebas menentukan kehendaknya dalam menyepakati sebuah perjanjian yang dibuatnya.

Berdasarkan uraian di atas, Pasal 1320 KUHPerdata dengan tegas mensyaratkan unsur-unsur yang harus dipenuhi agar sebuah perjanjian (kontrak) dapat dinyatakan sah. Dalam penulisan ini dibatasi pembahasan hanya mencakup salah satu unsur/syarat sahnya perjanjian yaitu kecakapan mereka untuk membuat suatu perikatan.

UU menentukan bahwa untuk dapat bertindak dalam hukum, seseorang harus telah cakap dan berwenang. Seseorang dapat di katakan telah cakap dan berwenang, harus memenuhi syarat-syarat yang di tentukan oleh peraturan yang berlaku yaitu telah dewasa, sehat pikirannya (tidak di bawah pengampuan), hal ini merupakan penafsiran secara a contrario dari Pasal 1320 KUHPerdata.

Kecakapan seseorang bertindak/berbuat hukum ditentukan dari belum atau telah dewasanya seseorang. Kedewasaan seseorang tersebut menjadi tolak ukur dalam menentukan apakah ia dapat atau tidak dapat melakukan pebuatan hukum. Perbuatan hukum di sini antara lain kedewasaan dalam mengadakan atau membuat perjanjian (kontrak). Undang-undang memberikan batasan kedewasaan berdasarkan umur. Pasal 330 KUHPerdata menegaskan usia dewasa seseorang apabila telah berusia 21 tahun dan telah menikah sebelum mencapai usia tersebut. Namun berdasarkan SEMA nomor 3/1963 juncto Pasal 31 Undang-undang nomor 1 tahun 1974, perempuan yang masih terikat dalam perkawinan sudah cakap melakukan perbuatan hukum sendiri

Perihal batasan usia dewasa, pernah menjadi polemik karena berbagai peraturan perundang-undangan mengaturnya secara berbeda, baik dari peraturan keperdataan maupun peraturan publik lainnya. Di bidang keperdataan saja, Pasal 47 
Undang-Undang Nomor 1 Tahun 1974 Tentang Perkawinan, menegaskan usia dewasa apabila lebih dari 18 tahun. Pasal 39 ayat (1) Undang-Undang Nomor 30 Tahun 2004 juncto Undang-Undang Nomor 2 Tahun 2014 Tentang Perubahan Undang-Undang Nomor 30 Tahun 2004 Tentang Jabatan Notaris, kecakapan seseorang yang bisa menghadap dan membuat perjanjian di Notaris, apabila usianya telah berumur 18 tahun. Sehingga usia dewasa untuk mengadakan perjanjian (kontrak) secara umum dapat dipergunakan batasan usia telah berumur 18 tahun.

Kecakapan berbuat hukum adalah merupakan kewenangan umum untuk melakukan tindakan hukum yang berlaku bagi manusia sebagai subjek hukum. Kecakapan berbuat hukum dari seorang subjek hukum, salah satunya mengadakan atau membuat perjanjian (kontrak) hanya dapat dilakukan oleh orang yang telah mencapai usia dewasa (penulis mengambil pendapat batasan usia dewasa 18 tahun), sehat pikirannya. Apabila ada perjanjian (kontrak) yang dibuat tidak memenuhi unsur/syarat sahnya perjanjian berupa syarat subjektif sehingga perjanjian (kontrak) tersebut dapat dibatalkan.

Pembuktian akan dilakukan jika terjadi sengketa atau upaya untuk melakukan pembatalan suatu kontrak. Pembuktian harus dilakukan oleh orang yang mendalilkan tentang adanya kerugian yang terjadi pada dirinya, dalam pembuatan kontrak elektronik, maka pihak yang merasa dirugikan karena pihak lain tidak memenuhi unsur kecakapan dan kewenangan, dialah yang harus membuktikannya.

Pembuktian yang dimaksud dalam penulisan ini dibatasi pada pembuktian dalam proses perdata, karena kontrak elektronik merupakan perbuatan hukum yang terjadi dalam bidang keperdataan. Pengertian pembuktiaan dalam proses perdata menurut Achmad Ali dan Wiwie Heryani:

"Upaya uang dilakukan oleh para pihak untuk menyelesaikan persengketaan mereka atau untuk memberi kepastian tentang benar terjadinya peristiwa hukum tertentu, dengan menggunakan alat bukti yang ditentukan hukum, sehingga dapat dihasilkan suatu penetapan atau putusan oleh pengadilan". 7

Pengaturan tentang alat-alat bukti, ternyata tegas dalam Pasal 1866 KUHPerdata. Dalam hukum perdata yang berlaku di Indonesia, alat bukti adalah berupa surat/tulisan, saksi, persangkaan, pengakuan, dan sumpah. Dari semua alat

\footnotetext{
${ }^{7}$ Achmad Ali dan Wwie Heryani,Asas-Asas Hukum Pembuktian Perdata,Prenadamedia Group, Jakarta,2015, hlm.21
} 
bukti tersebut di atas, alat bukti tulisan mendapat tempat yang utama. Setelah diterbitkannya UU ITE, kedudukan alat bukti dalam pembuktian transaksi elektronik berubah. Perubahan tersebut sebagaimana ditegaskan dalam Pasal 44 UU ITE, berdasarkan pasal tersebut dapat diketahui bahwa alat bukti elektronik memiliki kekuatan hukum yang sama dengan alat bukti lainnya yang telah terlebih dahulu diatur berdasarkan peraturan perundang-undangan. Artinya, alat bukti elektronik (dalam kontrak elektronik) diterima sebagai salah satu alat bukti yang sah, namun proses pembuktiannya terhadap kontrak elektronik yang terjadi sengketa, tetap mengikuti prosedur dan aturan pembuktian menurut KUPerdata dan Hukum Acara Perdata.

Persoalan akan timbul dari pembuktiaan alat-alat bukti dalam kontrak elektronik sebab dalam transaksi konvesional suatu perjanjian dibuat secara tertulis dan ditandatangani. Keadaan tersebut mempermudah pembuktian apabila terjadi sengketa mengenai perjanjian tersebut.Namun untuk pembuktian pada transaksi elektronik yang dilaksanakan dengan menggunakan media elektronik tanpa tatap muka para pihak, maka untuk melakukan pembuktian terkait dengan kecakapan dan kewenangan akan sangat suli dilakukan. Jikapun dapat dilakuan pembuktian maka terhadap sengketa kontrak elektronik , apabila kontrak elektronik tersebut tertuang dalam dokumen elektronik yang dipegang oleh pihak-pihak pembuat kontrak elektronik tersebut.

Hingga saaat ini dokumen elektronik dapat dijadikan alat bukti dan digunakan proses persidangan, namun dokumen elektronik tersebut menjadi pertimbangan hakim karena bahan kontrak elektronik tidak sama dengan seperti alat bukti tertulis pada kontrak konvesional.Sehingga soal pembuktian kontrak elektronik masih menimbulkan permasalahan dalam proses pengadilan di Indonesia.

\section{Penutup}

\section{Kesimpulan}

Pembuktian pada transaksi elektronik yang dilaksanakan dengan menggunakan media elektronik tanpa tatap muka para pihak, maka untuk melakukan pembuktian terkait dengan kecakapan dan kewenangan akan sangat suli dilakukan. Jikapun dapat dilakuan pembuktian maka terhadap sengketa 
kontrak elektronik, apabila kontrak elektronik tersebut tertuang dalam dokumen elektronik yang dipegang oleh pihak-pihak pembuat kontrak elektronik tersebut. Hingga saaat ini dokumen elektronik dapat dijadikan alat bukti dan digunakan proses persidangan, namun dokumen elektronik tersebut menjadi pertimbangan hakim karena bahan kontrak elektronik tidak sama dengan seperti alat bukti tertulis pada kontrak konvesional.Sehingga soal pembuktian kontrak elektronik masih menimbulkan permasalahan dalam proses pengadilan di Indonesia

\section{Saran-saran}

1. Sebelum menandatangani perjanjian bisnis debitur, seharusnya terlebih dahulu mencermati draft perjanjian bisnis sebab banyak klausul-klausul dalam penerapan perjanjian isinya merugikan debitur.

2. Bagi Konsumen agar lebih berhati-hati dalam melakukan transaksi elektronik mengingat antara konsumen dan pelaku usaha tidak saling bertatap muka dan tidak saling mengenal, maka tindak kecurangan dari pelaku usaha yang tidak beretikad baik akan lebih mudah muncul. Oleh karena itu, perlu sikap teliti serta waspada dari konsumen dalam melakukan kesepakatan dalam transaksi elektronik

\section{DAFTAR PUSTAKA}

Achmad Ali dan Wwie Heryani,Asas-Asas Hukum Pembuktian Perdata,Prenadamedia Group, Jakarta,2015

Agus Raharjo, Cybercrime: Pemahaman dan Upaya Pencegahan Kejahatan Berteknologi, PT. Citra Aditya Bakti, Bandung, 2002

Ari Juliano Gema, Apakah Dokumen Elektronik Dapat Menjadi Alat Bukti yang Sah, Jurnal PERADI, 7 April 2008

AsrilSitompul, Hukum Internet (Pengenal Mengenai Masalah Hukum di Cyberspace), $\mathrm{C}$ etak an II, , PT.Citra Aditya Bakti, Bandung, 2004

M. Arsyad Sanusi, E-Commerce: Hukum dan Solusinya, P.T. Mizan Grafika Sarana, Bandung, 2001 


\section{DAFTAR PUSTAKA}

\section{BUKU-BUKU :}

Abdul Kadir Muhammad, Hukum Perdata Indonesia. Citra Aditya. Bakti , Bandung, 2010

Ahmadi Miru,Hukum Kontrak dan Perencanaan Kontrak ,(PT RajaGrafindoPersada, Jakarta, 2007

Agus Yudha Hernako, Hukum Perjanjian, Kencana Prenada Media Group, Jakarta. 2010

Bambang Sunggono, Penelitian Hukum ,Radja Grafindo, Jakarta, 2012

Burhan Ashshofa, Metode Penelitian Hukum, Rineka Cipta, Jakarta , 2001

Bruggink J.J.H. Refleksi Tentang Hukum Pengertian-Pengertian Dasar Dalam Teori Hukum, Terjemahan Arief Shidarta, Citra Aditya Bakti, Bandung., 1996

Christiana Tri Budhayati, "Asas Kebebasan Berkontrak Dalam Hukum Perjanjian di Indonesia”, Jurnal Widya Sari, Vol. 10 No. 3 Januari 2009

Henry Campebelt Black, Black's Law ,Dictionary,Defenitions of the Terms and Phrases of American and English Jurisprudence Ancient and Modern,West Publhising Co,St.Paul Minn, 1986

Herlien Budiono, Kumpulan Tulisan Hukum Perdata di Bidang Kenoktariatan,Citra Adytia Bakti,Jakarta,2013

Asas Keseimbangan bagi Hukum Perjanjian Indonesia (Hukum Perjanjian Berlandaskan Asas-Asas Wigati Indonesia), Citra Aditya Bakti, Bandung: 2006

Herlin Budiono dalam Muhammad Syaifuddin, Hukum Kontrak Memahami Kontrak dalam Perspektif Filsafat, Teori, Dogmatik, dan Praktik Hukum, Mandar Maju,, Bandung,2012

Gemala Dewi, Aspek-aspek Hukum Dalam Perbankan dan Perasuransian Syariah, Kencana, Jakarta, 2004

Kartini Mulyadi dan Gunawan Widjaya,Perikatan Yang Lahir Drai Perjanjian,PT.Grafindo Persada,Jakarta, 2010

Mariam Darus Badrulzaman, KUHPerdata Buku III Hukum Perikatan dengan penjelasan, Alumni, Bandung, 1983 
Muhammad Syaifuddin, Hukum Kontrak, Memahami Kontrak dalam Perspektif Filsafat, Teori, Dogmatik, dan Praktik Hukum, Mandar Maju, Bandung, 2012

Munir Fuady, Hukum Kontrak (Dari Sudut Pandang Hukum Bisnis), Buku Kedua, Citra Aditya Bakti, Bandung, 2003

-------- , Hukum Perjanjian,Dari Sudut Pandang Hukum Bisnis, Citra Aditya Bakti, Bandung, 2001,

Peter Mahmud Marzuki, Kontrak Dagang Internasional, Universitas Merdeka,Malang, 2018

P.N.H.SimanjuntakHukum Perdata Indonesia: Edisi Pertama, Prenadamedia Group, Jakarta, 2015

P.S Atiyah, An Introduction To The Law Of Contract, Clarendo Press, Oxford, 1984

Purwahid Patrik, Dasar-Dasar Hukum Perikatan, Mandar Maju Bandung 1994

Ronny Hanityo Soemitro, Metodologi Penelitian Hukum Dan Jurimetri, Ghalia Indonesia, Jakarta, 1980

Ricardo Simanjutak, Hukum Kontrak: Teknik Perancangan Kontrak Bisnis, Kontan Fublhising, Jakarta, 2011

R.Subekti, Hukum Perjanjian,Intermasa, Jakarta,1996

Aspek-Aspek Hukum Perikatan Nasional, Alumni, Bandung, 1996

Salim H.S, , Hukum Kontrak: Teori \& Teknik Penyusunan Kontrak, Sinar Grafika Jakarta ,2003

, Pengantar Hukum Perdata Tertulis (BW), Sinar Grafika Jakarta,1996

, Hukum Kontrak Teori Dan Teknik Penyusaunan Kontrak, Sinar Grafika, Jakarta, 2013

Salim, Abdulah, Perancangan kontrak \& Memorandum of Understanding, Sinar Grafika, Jakarta, 2007

Sofhar Maru Hutagalung,Kontrak Bisnis di Asean pengaruh Sistem Common Law dan Civil Law,Sinar grafika,Jakarta,2013

Suharnoko, Hukum Perjanjian, Prenada Media, Jakarta, 2004

Suratman dan Philisp Dillah,Metode Penelitian Hukum, Alfabeta,Bandung,2012 
Sjahdeini Remy Sutan,Kebebasan Berkontrak dan Perlindungan yang Seimbang,Institut Bankir Indonesia, 1993

Tim Penyusun Kamus Pembinaan dalam Muhammad Syaifuddin, , Hukum Kontrak Memahami Kontrak dalam Perspektif Filsafat, Teori, Dogmatik, dan Praktik Hukum, Mandar Maju, Bandung,2012

Taufik el Rahman dan kawan-kawan., "Asas Kebebasan Berkontrak dan Asas Kepribadian dalam Kontrak-kontrak Outsourcing”,Mimbar Hukum, Vol. 23, No. 3, Oktober 2011

Yunirman Rijan, Ira Koesoemawati, Ke Notaris,,Raih Asa Sukses,Jakarta, 2009 